\title{
Bubbl.us - Web 2.0 Mind Mapping
}

Nola Stair

Faculty of Business, University of Greenwich

\section{Introduction}

Do your students have a hard time getting started and planning their essays? Do they struggle with narrowing down appropriate dissertation topics? Or maybe your students want you to approve their research questions without having thought through supporting academic resources?

If so, consider incorporating the use of mind maps as one of your teaching strategies. Mind maps, one type of visual organizer, can be very effective with helping students organize their thoughts while brainstorming (Davies 2011). In addition, there are a variety of mind mapping software tools available, such as Inspiration offered via the University of Greenwich network. From my own personal exploration, some software based programs are often too complicated and/or too sophisticated for free flowing content development and need to be downloaded/installed. However, I have finally come across a useful online application that seamlessly enhances student-student and student-tutor engagement - Bubbl.us - which is based upon Web 2.0 technology and facilitates an interactive online sharing of mind maps among students and/or with their tutors.

\section{Teaching}

In Thematic Independent Studies (TIS) offered by the Systems Management and Strategy Department in the Business School, Year 3 students are expected to write a literature review (4000 words) and critical analysis/argument about their literature review (5000 words).

Mind maps have been helpful in engaging students in research-related discussions about their potential topics. At first, mind map templates were simply added as an appendix to the course handbook and tutors were encouraged to use them during the course's first tutorial. Typically, as guided practice, the tutor would create a mind map with the entire class using the visualizer (or MS Word on the overhead projector and a familiar Business-related topic). Once the "crowd sourced" mind map was created, this sparked additional ideas and students began suggesting their own topics - often in hopes of another "crowd-sourced" mind map for their own essay topic.

Previous research has already shown the effectiveness of mind maps to facilitate meaningful learning (Reima, 2009). Paper-based mind maps were working well; however, I continued to evaluate mind map software to support students' digital literacy; and stumbled across Bubbl.us a "free" tool for online brainstorming. At first, a link to Bubbl.us was placed in the TIS Moodle course site, encouraging students to use it instead of the paper-based template. The basic features of Bubbl.us can be used without creating a user id or password (i.e., create/print) however, if you choose to create a free account, this will enable the saving feature. As TIS students are required to include their mind maps and research logs as part of their reflective 
report at the end of the course, Bubbl.us-generated mind maps started appearing in their coursework submissions.

As the TIS course leader, I began to encourage students to share their mind maps with me online, instead of bringing hard copies to tutorials or during individual appointments with nonattending or late registering students. In order to enable the Bubbl.us sharing feature, I had to upgrade from the "free" account to the "annual" account for £25, which includes an educational discount. With Bubbl.us, students were able to finalize their mind maps online and share them with me in several ways:

- via a read-only link (embedded in emails)

- via Bubbl.us - which allowed me to easily add my own comments or suggestions. These insertions are instantly visible to students.

Also, if you teach in a room with a SMART board, drawing a mind map is one of the easiest ways of becoming used to using a whiteboard. Using Bubbl.us on a SMART board is very practical whiteboard application.

\section{Learning}

As a result, students began creating multiple mind maps before and during tutorials (see Figure 1). Group discussions were able pinpoint similar areas of interest, allowing for smaller groups to form and discuss topics in more detail. Students expressed the following thoughts in their reflective reports:

- "I've created several mind maps...At first, I was thinking about writing about Leadership, but l've now narrowed it down to Managers vs Leaders. I never realized the importance of brainstorming!"

- "The mind map is something I have never done for coursework before, but it was very helpful to write down ideas and to find new ideas by linking them together. I will do mind maps for future work and projects not just for educational work but also for when it comes to my career and future projects."

Figure 1: Sample Mind Map created by Year 3 Direct Entry Chinese student

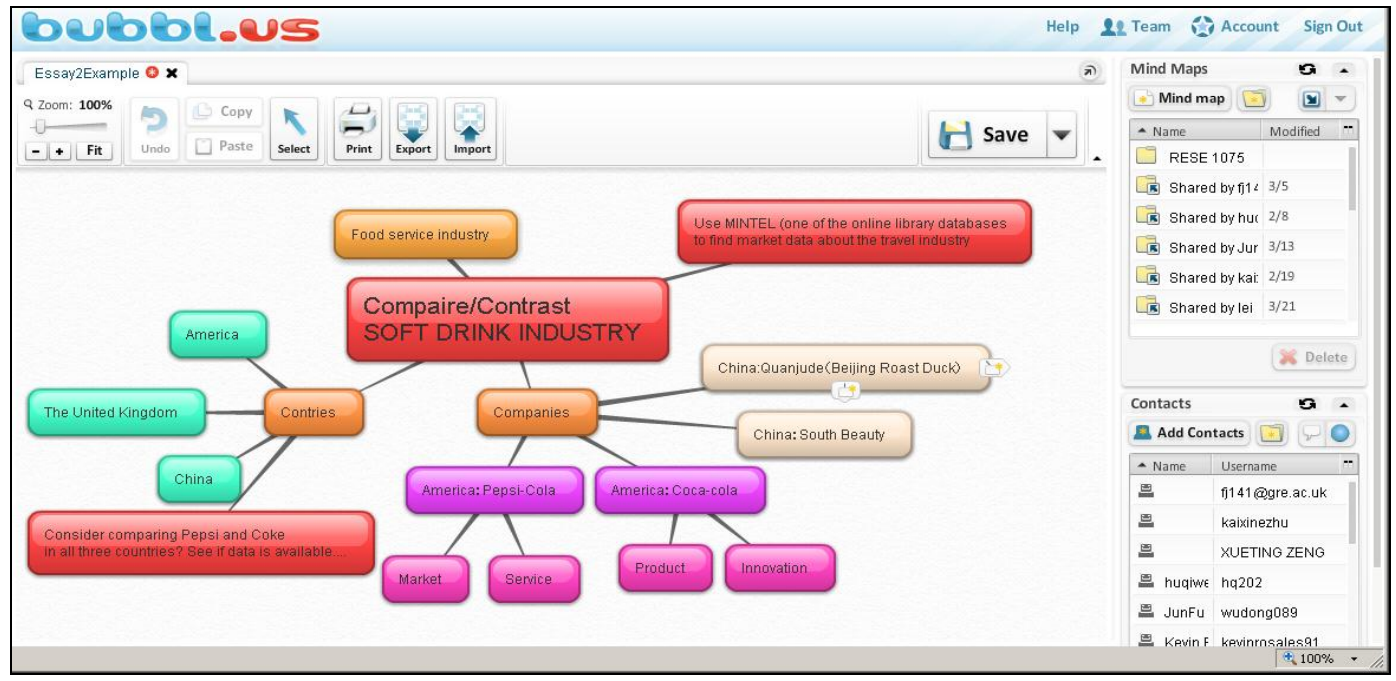

Compass: The Journal of Learning and Teaching at the University of Greenwich, Issue 8, 2013 
In addition, during their library session on "Using Academic Journal Databases", students were reminded that they could use the same key words on their mind map as search terms in the online databases. This provided additional usability as another student reflected:

- "I believe my preparation for my second essay was better than the first as I formulated my mind map on time and started getting my ideas together. This helped me to put together my sub themes fairly quickly, whereas for the first essay I was unsure how to go about it and confused about how to divide my essay into subthemes. My mind map for my second essay was more detailed and helped me to acquire my articles with ease as I knew exactly what to put in the search box. This helped me realise that mind maps are a very good method for jotting down all ideas and then selecting the most important points from these to formulate my essay."

After exploring how Bubbl.us has increased active engagement between students and tutors and helped to promote deep vs surface learning, what are the advantages and disadvantages of the Bubbl.us tool itself? Some thoughts are summarized in Table 1 below:

Table 1: SWOT Analysis

\begin{tabular}{|c|c|}
\hline $\begin{array}{l}\text { Strengths } \\
\text { - User friendly and easy to use } \\
\text { - Can develop/print mind maps without } \\
\text { - "Draunt creation } \\
\text { editing, re-linking of concepts, and } \\
\text { changing positions of sub-topics } \\
\text { - Collaborative development } \\
\text { - No downloads necessary, browser- } \\
\text { based }\end{array}$ & $\begin{array}{l}\text { Weakness } \\
\text { - Flash-based (doesn't work on iPads) } \\
\text { - Requires free account creation to save } \\
\text { mind maps } \\
\text { - Requires premium account (by } \\
\text { lecturer) to allow collaborative sharing } \\
\text { of mind maps }\end{array}$ \\
\hline $\begin{array}{l}\text { Opportunities } \\
\text { - Educational discount available for } \\
\text { premium accounts } \\
\text { - Team accounts for special projects }\end{array}$ & $\begin{array}{l}\text { Threats } \\
\text { - Similar free web-based tools, such as } \\
\text { MindMeister, XMind, FreeMind }\end{array}$ \\
\hline
\end{tabular}

\section{Conclusion}

Most often, when thinking about mapping knowledge, brainstorming through the use of mind maps comes to mind first. However, Bubbl.us can also be used for developing argument and concept maps. According to Davies (2011), mind maps are less formal and structured; while concept maps are structured more hierarchically using relational phrases and argument maps to explicate inferential structures.

Pen and paper mind maps won't ever go away, but visit http://bubbl.us and see how easy it is to brainstorm your ideas! I've just seen a new feature recently added to Bubbl.us, allowing your bubbles to link to websites. See you online! 


\section{Technology Reviews}

\section{Bibliography}

Davies, M. (2011). 'Concept mapping, mind mapping, and argument mapping: what are the differences and do they matter?', Higher Education, 62, pp. 279-301.

Reima, A. (2009). 'Enhancing Freshman Students' Writing Skills with Mind-Mapping Software.' The $5^{\text {th }}$ International Scientifics Conference - eLearning and Software for Education Bucharest.

Rich, M. (2011). 'Student Research in a Web 2 World: Learning to use new Technology to Gather Primary Data.' The Electronic Journal of Business Research Methods Volume 9 Issue 1 2011 (78-86). Available at http://www.ejbrm.com. (Accessed May 18, 2013).

Torrance, M., Thomas, G. V., \& Robinson, E. J. (2000). 'Individual differences in undergraduate essay-writing strategies: A longitudinal study.' Higher Education, 39(2), 181-200.

\section{Author Biography}

Nola Stair is a principal lecturer in International Collaborations and Learning Technology in the Business School's department of Systems Management and Strategy. She has published in the areas of eLearning/Instructional Design Technology and has presented at various international conferences. 